\title{
Spread of Phytophthora cinnamomi in a naturally Infested Vineyard Soil ${ }^{1}$
}

\author{
P. G. MARAIS ${ }^{\mathrm{a}}$ and M. J. HATTINGH \\ (a) Viticultural and Oenological Research Institute (VORI), Private Bag X5026, 7600 Stellenbosch, Republic of South Africa. \\ (b) Department of Plant Pathology, University of Stellenbosch, 7600 Stellenbosch, Republic of South Africa.
}

Submitted for Publication: August 1984

Accepted for Publication: March 1985

Keywords: Phytophthora cinnamomi; vineyards

\begin{abstract}
Phytophthora cinnamomi Rands. was isolated from rootstocks of dead or diseased vines in vineyards from 14 districts in the Cape Province of South Africa. It was recovered in vineyard soil to a depth of $320 \mathrm{~mm}$. Downhill spread of the pathogen was more rapid through a soil with a perched water table (Estcourt: Rosmead soil series) than through a freely draining soil (Clovelly: Blinkklip soil series). Lateral movement of the fungus through soil occurred to a limited extent. The disease potential index of newly ingested soil was usually higher than that of areas previously infested. The results indicated the danger of introducing $P$. cinnamomi to poorly drained soils by planting infected vines.
\end{abstract}

The devastation caused by Phytophthora cinnamomi Rands in Australian and New Zealand forests illustrates the ability of the pathogen to spread. (Newhook \& Podger, 1972). In South Africa a single infected tree introduced at planting into a block of over 500 avocado trees resulted in the entire grove being abandoned within 10 years because of root rot (Brodrick \& Frean, 1973).

A survey of South African vineyards indicated that $P$. cinnamomi is one of the most important root pathogens of grapevines (Marais, 1979a). The rootstock 99 Richter is used extensively in this country, especially on heavier textured, slower draining soils and is particularly susceptible to root rot (Marais, 1979b). In one locality about $50 \%$ of 60000 vines on 99 Richter rootstock were dead or in various stages of decline within 6 months after planting (Marais, 1979a).

The present study was undertaken to determine the occurrence of $P$. cinnamomi in vineyards in the Western Cape Province and its spread in a naturally infested vineyard soil.

\section{MATERIALS AND METHODS}

Geographic distribution of $P$. cinnamomi: A survey on the distribution of P. cinnamomi within the Western Cape Province, where 11 districts were covered and sampling methods explained were published by Marais (1979a). Some of the data not reported in the previous article are presented.

Spread of $P$. cinnamomi through soil: The spread of $P$. cinnamomi was determined in naturally infested vineyard soil on the experimental farm Nietvoorbij of the Viticultural and Oenological Research Institute, Stellenbosch. The vineyard studied was an 8 year old Vitis vinifera $\mathrm{cv}$. Cape Riesling (synonym Crouchen blanc) grafted on 99 Richter and was situated on an $8 \%$ slope. The dominant soilforms in the vineyard were classified as Estcourt (Rosmead soil series) and Clovelly (Blinkklip soil series) (MacVicar, et al., 1977). The Estcourt is a soil with an orthic A horizon over an $\mathrm{E}$ horizon over a prismacutanic B horizon. This E horizon contains 15 to $35 \%$ clay and is slightly impervious to water. The Clovelly consists of an orthic A over a yellow-brown apedal B horizon. While the
B horizon in the soil also contains 15 to $35 \%$ clay it does not impede water penetration and drains well.

Vertical distribution: Vertical distribution of $P$. cinnamomi was determined in soil cores obtained by means of a $30 \mathrm{~mm}$ diameter auger to a depth of $560 \mathrm{~mm}$, from four sites $15 \mathrm{~cm}$ from the trunk of five infected vines in each soilform. The auger was sterilised after each sampling. The cores were divided into seven $80 \mathrm{~mm}$ subsamples which were pooled according to depth and stored moist until tested. The presence of the pathogen in $10 \mathrm{~g}$ soil was determined by the lupin baiting method (Chee \& Newhook, 1965).

Horizontal spread: To determine uphill, downhill and lateral spread of the fungus the vineyard was divided into 1500 plots of equal size $\left(3 \mathrm{~m}^{2}\right)$. One soil sample was taken from each plot to a depth of $300 \mathrm{~mm}$ with the auger. Sampling was then repeated at 6 monthly intervals for 24 months by taking twenty samples from each plot. Only plots which were initially recorded as being infested, and bordering plots were subsequently sampled. All samples were stored moist until tested and the presence of the pathogen determined by the lupin baiting method. Development of disease symptoms was recorded and isolations were made from roots of healthy and diseased vines as described by Marais (1979a).

Disease potential index (DPI): The soil auger was used to collect five soil samples $60 \mathrm{~cm}$ from the trunk and to a depth of $300 \mathrm{~mm}$ around each of 10 healthy, 10 diseased and 10 dead vines within the same vineyard. A similar sampling was made of soil around vines growing within areas of the vineyard where soil infestation had only recently been detected. Samples were taken during winter when soil temperature were relatively low and soil moisture high. The DPI of each soil sample (reciprocal of the maximum dilution from which the pathogen was isolated) was determined as described by Tsao (1960).

\section{RESULTS AND DISCUSSION}

Geographic distribution of $P$. cinnamomi: $P$. cinnamomi was isolated from dead or dying grapevines on different rootstocks in vineyards from 14 districts of the Western 
Cape Province. It was isolated from vines in 69 of 114 vineyards surveyed but was recovered from soil around infected vines in only 11 vineyards (Table 1 ).

TABLE 1

Presence of Phytophthora cinnamomi Rands in soil and grapevine roots from vineyards in the South-Western Cape Province*

\begin{tabular}{|c|c|c|c|c|}
\hline \multirow{3}{*}{ Location } & \multirow{3}{*}{ Rootstock } & \multicolumn{3}{|c|}{ Number of vineyards: } \\
\hline & & \multirow[t]{2}{*}{ Sampled } & \multicolumn{2}{|c|}{$\begin{array}{l}P \text {. cinnamomi } \\
\text { isolated }\end{array}$} \\
\hline & & & Roots & Soil \\
\hline De Doorns & 99 Richter & 2 & 2 & 2 \\
\hline Franschhoek & 99 Richter & 2 & 1 & 0 \\
\hline Malmesbury & 99 Richter & 9 & 6 & 1 \\
\hline \multirow[t]{2}{*}{ Montagu } & $\begin{array}{l}99 \text { Richter } \\
\text { Vitis rupetris }\end{array}$ & 4 & 2 & 1 \\
\hline & var. du Lot & 2 & 2 & 0 \\
\hline Oudtshoorn & 99 Richter & 1 & 1 & 0 \\
\hline Paarl & 99 Richter & 19 & 11 & 2 \\
\hline Porterville & 99 Richter & 3 & 1 & 0 \\
\hline \multicolumn{5}{|l|}{ Riebeek- } \\
\hline Kasteel & 99 Richter & 2 & 2 & 0 \\
\hline Robertson & 99 Richter & 2 & 1 & 0 \\
\hline \multicolumn{5}{|l|}{ Somerset } \\
\hline West & 99 Richter & 4 & 2 & 1 \\
\hline \multirow[t]{2}{*}{ Stellenbosch } & $\begin{array}{l}99 \text { Richter } \\
V \text { rupestris }\end{array}$ & 23 & 13 & 2 \\
\hline & var. du Lot & 2 & 2 & 0 \\
\hline Tulbagh & 99 Richter & 1 & 1 & 0 \\
\hline \multirow[t]{4}{*}{ Wellington } & 99 Richter & 25 & 13 & 2 \\
\hline & $101-14 \mathrm{Mgt}$ & 3 & 3 & 0 \\
\hline & $V$. rupestris & & & \\
\hline & var. du Lot & 4 & 4 & 0 \\
\hline \multirow[t]{2}{*}{ Worcester } & 99 Richter & 6 & 2 & 0 \\
\hline & Totals & 114 & 69 & 11 \\
\hline
\end{tabular}

* Only vineyards suspected to be infected with P. cinnamomi were inspected.

Spread of $P$. cinnamomi through soil:

Vertical distribution: The pathogen was isolated to an average depth of $320 \mathrm{~mm}$ from the sampling sites in the Clovelly and to a depth of $240 \mathrm{~mm}$ from the Estcourt sampling sites. Vertical distribution of the pathogen thus appears to be related to soilform and to be restricted to the upper part of the root zone of the grapevine. This agrees with Weste, Cooke \& Taylor (1973) who found $P$. cinnamomi to depths of $160-240 \mathrm{~mm}$ in soil from under eucalypts. However, it differs considerably from results of Brodrick, Zentmyer \& Wood (1976) who found P. cinnamomi at depths of 600 to $1050 \mathrm{~mm}$ in soil under avocado trees in Southern California.

Horizontal spread: $P$. cinnamomi moved downhill for the first year in the Estcourt soil at a rate of $6 \mathrm{~m}$ per 6 months. At that time it reached the Clovelly soil and further downhill movement was progressively slowed and the fungus advanced only $6 \mathrm{~m}$ in 18 months. Gravitational water movement in the perched water table in the Estcourt soil probably contributed to the higher rate of movement of the pathogen compared to that in the Clovelly soil. A water table or clay barrier does not exist in the Clovelly soil and water tends to drain away to deeper layers.
Little lateral spread of the pathogen occurred in either of the two soils: approximately $1 \mathrm{~m}$ during the first year with hardly any further spread during the following 18 months. Lateral spread was not affected by soil type. Uphill spread was hardly ever detected. This indicated that $P$. cinnamomi spreads in vineyard soil mainly by water movement. Similar results were previously obtained by Podger (1972) and Weste (1975) in Australian forests and Zentmyer \& Ohr (1978) in avocado groves in California.

P. cinnamomi was isolated from all dead or diseased vines. The fungus was always detected in soil before symptoms developed. Not all vines in an infested area developed symptoms at the same time and plants died off in patches. The fungus was isolated from roots of only $2 \%$ of seemingly healthy vines within infested areas. The percentage vines showing symptoms in the experimental vineyard increased from $1,5 \%$ to $12,5 \%$ over a period of 36 months.

Disease potential index: With one exception, the DPI values of recently infested soil seemed to be higher or equal to those of older infested areas (Table 2). The DPI values of soil from below dead or diseased vines were also higher than those of soil from below healthy vines. Diseased vines therefore apparently act as a source from which inoculum spreads through the soil to healthy vines. Infected nursery material will therefore be an effective source of inoculum when planted into a vineyard, especially in poorly drained soils where horizontal spread of the fungus occurs in soil water.

TABLE 2

Disease potential index (DPI) ${ }^{\mathrm{a}}$ of soil below healthy, diseased and dead grapevines.

\begin{tabular}{c|c|c|c|c|c}
\hline \multicolumn{5}{c}{ DPI of soil below } \\
\hline \multicolumn{2}{c}{ Healthy vines } & \multicolumn{2}{c}{ Diseased vines } & \multicolumn{2}{c}{ Dead vines } \\
\hline $\begin{array}{c}\text { Old in- } \\
\text { festation }\end{array}$ & $\begin{array}{c}\text { Recent } \\
\text { infesta- } \\
\text { tion }\end{array}$ & $\begin{array}{c}\text { Old in- } \\
\text { festation }\end{array}$ & $\begin{array}{c}\text { Recent } \\
\text { infesta- } \\
\text { tion }\end{array}$ & $\begin{array}{c}\text { Old in- } \\
\text { festation }\end{array}$ & $\begin{array}{c}\text { Recent } \\
\text { infesta- } \\
\text { tion }\end{array}$ \\
\hline 1 & 1 & 2 & 8 & 4 & 8 \\
0 & 1 & 4 & 4 & 2 & 16 \\
2 & 1 & 8 & 16 & 4 & 8 \\
1 & 2 & 4 & 4 & 4 & 4 \\
1 & 1 & 2 & 8 & 8 & 8 \\
0 & 1 & 2 & 4 & 2 & 8 \\
\hline
\end{tabular}

a Determined by the method of Tsao (1960).

\section{CONCLUSIONS}

Diseased vines act as a source from which inoculum of $P$. cinnamomi spreads through the soil to healthy vines. $P$. cinnamomi spread in vineyard soil mainly by water movement and soil with a clay barrier or a perched water table like Estcourt, contributes to a high rate of movement of the pathogen. Other hosts of $P$. cinnamomi like Proteaceae may also act as an inoculum source. When a new vineyard is planted on Estcourt soil, care should therefore be taken to plant rootstocks resistant to $P$. cinnamomi. 


\section{REFERENCES}

BRODRICK, H. T. \& FREAN, R. T., 1973. Avocado growers beware of root rot Cirtus Subtrop. Fruit. J. Jan. 1973, 6-8.

BRODRICK, H. T., ZENTMYER, G. A. \& WOOD, R., 1976. Comparison of various methods for the isolation of Phytophthora cinnamomi from avocado soils. Calif. Avocado Soc. Yearb. 59 87-91.

CHEE, K. \& NEWHOOK, F. S., 1965. Improved methods for use in studies on Phytophthora cinnamomi and other Phytophthora species. N. Z. J1. Agr. Res. 8, 88-95.

MacVICAR, C. N., et al., 1977. Soil classification - a binomial system for South Africa. Dept. Agricultural Technical Services, 0001 Pretoria, R.S.A.

MARAIS, P. G., 1979a. Fungi associated with root rot in vineyards in the Western Cape. Phytophylactica 11, 65-68.

MARAIS, P. G., 1979b. Situation des porte-greffes résistants à Phytophthora cinnamomi. Bull. Off. Vit. Vin. 579, 357-376.

NEWHOOK, F. J. \& PODGER, F. D., 1972. The role of Phytophthora cinnamomi in Australian and New Zealand forests. Ann. Rev Phytopathol. 10, 299-326.

PODGER, F. D., 1972. Phytophthora cinnamomi, a cause of lethal disease in indigenous plant communities in Western Australia. Phytopathology 62, 972-981.

TSAO, P. H., 1960. A serial dilution end point method for estimating disease potential of citrus phytophthoras in soil. Phytopathology 50, 717-724.

WESTE, G., 1975. The distribution of Phytophthora cinnamomi within the National Park Wilson's Promontory, Victoria. Aust. J. Bot., 23, 67-76.

WESTE, G., COOKE, D. \& TAYLOR, P., 1973. The invasion of native forest by Phytophthora cinnamomi. II. Post-infection vegetation patterns, regeneration, decline in inoculum, and attempted control Aust. J. Bot., 21, 13-29.

ZENTMYER, G. A. \& OHR, H. D., 1978. Avocado root rot. Univ. Calif. Div. Agric. Sci. Leafl. 2440. 